SISTEMA
ELETRONIICO
DE REVISTAS
SER I UfPR

\title{
Challenges of performing socio-environmental interdisciplinary research: the experience of the Brazilian Research Network on Climate Change (Rede CLIMA)
}

\section{Os desafios da pesquisa socioambiental interdisciplinar: a experiência da Rede Brasileira de Pesquisa Sobre Mudanças Globais (Rede CLIMA)}

\author{
Gabriela LITRE $^{1,2^{*}}$, Marcel BURSZTYN${ }^{1}$, Saulo RODRIGUES FILHO ${ }^{1}$, Patricia MESQUITA ${ }^{1}$ \\ ${ }^{1}$ Centro de Desenvolvimento Sustentável (CDS), Universidade de Brasília (UnB), Brasília, DF, Brasil. \\ ${ }^{2}$ Rede Brasileira de Pesquisa sobre as Mudanças Climáticas (Rede CLIMA), Instituto Nacional de Pesquisas Espaciais (INPE), São José dos \\ Campos, SP, Brasil. \\ *E-mail of contact: gabrielalitre@yahoo.com
}

Article received on July 5, 2018, final version accepted on May 21, 2019.

\begin{abstract}
How can you move a team of scholars of the most varied academic backgrounds out of their multidisciplinary comfort zone and towards genuine interdisciplinarity (integration and collaboration) in the climate change research field? This was the challenge that a project faced concerning the climate change perceptions of smallholder farmers from four Brazilian biomes (Amazonia, Cerrado, Pantanal, and Semiarid region), coordinated by the Brazilian Research Network on Climate Change (Rede CLIMA). Interdisciplinary clashes among scientists went well beyond semantics and reached the core of concepts such as perception, resilience, vulnerability, adaptive capacity and even climate change. Challenges included thinking collectively about a problem with so much ambiguous and contradictory knowledge, conflicting interests, and diverging epistemologies. This case study - which focused on the internal debate about climatic change apparent "misperceptions" by family farmers - confirmed that there is no blueprint for interdisciplinary climate change research projects, as well as the clear need for project-specific and context-sensitive research strategies. Critical factors going into successful interdisciplinary and transdisciplinary integration included early involvement of different groups (such as researchers, decision-makers, and local actors and stakeholders) as essential for finding common objectives and priorities. The experience of Rede CLIMA confirmed that the barriers to successful climate change adaptation (such as the mutual incomprehension or distrust between scientists themselves, and between scientist and end-users) could be overcome by creating collaborative enterprises. The co-creation of science, which included switching roles between knowledge producers and endusers, facilitated horizontal work and the identification of climate-related risks among family farmers.
\end{abstract}

Keywords: climate change; interdisciplinarity; adaptation; misperceptions. 
Como conseguir que um grupo de especialistas com as mais variadas expertises saia de sua zona de conforto e pratique uma genuína interdisciplinaridade (colaborativa e integrada) no campo das pesquisas socioambientais sobre mudanças climáticas? Esse foi o desafio encarado por um projeto de pesquisa sobre as percepções de agricultores familiares da Amazônia, Cerrado, Pantanal e Caatinga, sobre os impactos que as mudanças climáticas estão tendo nos seus modos de vida. As diferenças disciplinares não demoraram a ficar evidentes. Foi difícil pensar de maneira coletiva sobre algum problema quando as linguagens acadêmicas resultantes foram diferentes e até conflitantes. As diferenças iam além do semântico e levavam a compreensões diferenciadas de termos como resiliência, vulnerabilidade, capacidade adaptativa e o próprio conceito de mudanças climáticas. Como harmonizar essas definições para conseguir enxergar de maneira integrada uma realidade complexa e totalmente nova? O presente estudo de caso - que focalizou no debate interno sobre as aparentes "falsas percepções" sobre as mudanças climáticas, isto é, quando as percepções dos agricultores sobre essas mudanças não são confirmadas por dados climatológicos "duros" sobre tendências de temperatura e pluviométricas - demonstra que não existem receitas rígidas para a execução de projetos interdisciplinares de pesquisa socioambientais, bem como a necessidade de desenhar protocolos de pesquisa sensíveis a cada contexto. Alguns dos fatores críticos para o sucesso incluíram o envolvimento precoce de diferentes grupos (como pesquisadores, tomadores de decisão e atores locais) desde as primeiras fases da pesquisa, incluindo na definição de perguntas, objetivos e problemas comuns. A experiência confirmou que as barreiras para uma adaptação bem-sucedida às mudanças climáticas (como a incompreensão ou desconfiança mútua) poderiam ser superadas através da criação de iniciativas colaborativas que permitam a cocriação de estratégias de adaptação, incluindo a troca de papéis entre produtores de conhecimento e usuários finais, facilitando o trabalho horizontal.

Palavras-chave: mudanças climáticas; interdisciplinaridade; adaptação; falsas percepções.

\section{Introduction}

Unlike the experiences of many fields, the environmental studies in the social sciences were not developed through the gradual consideration of major environmental paradigms - what Kuhn called "normal" or incremental Science (Kuhn, 1962). On the contrary, the rapid irruption of serious environmental problems and, above all, of socio-environmental movements placed the issue on social science agendas (Hogan, 2007, p. 161). Although many social scientists studied the human determinants and consequences of environmental change, in general, they were unprepared to incorporate global changes in their working scope, while available funds continued to be invested on climate and biosphere-related research (Janssen et al, 2006). In comparison, investments in interdisciplinary and social sciences research on topics such as mitigation and adaptation processes and perceptions about climate change were still quite modest (Smit \& Wandel, 2006). Adding to the limited financial resources, the challenges of inter and multi disciplinary research, that is "always stretching the vision - and often the patience - of 'normal' scientists", can be considerably amplified when collaboration seeks to bridge the gap between natural and social science (Hogan, 2007, p. 161).

Ten years after this diagnosis, the issue of human dimensions of global changes, and specifically of climate change, has been progressively incorporated into Brazil's national, subnational and municipal policies and economic instruments. In 2009, the federal administration instituted the National Climate Change Policy (Law 12.187/2009) and the related implementation mechanisms, the National 
Climate Change Plan (PNMC, 2008). Local administrations, such as those in the states of São Paulo, Pernambuco, Paraná, Bahia and Rio de Janeiro, and in the cities of São Paulo and Rio de Janeiro, created similar instruments at the subnational level. At the same time, in 2009, the federal administration also instituted the Brazilian Network on Global Climate Change Research (hereafter Rede CLIMA).

Rede CLIMA was conceived to become Brazil's main scientific research and development institution in the climate change arena. One of rede CLIMA's sixteen research sub-networks, the Climate Change and Regional Development sub-network ( $M C D R$, in Portuguese) coordinated by the Centre for Sustainable Development of the University of Brasilia (CDS-UnB), has led an important effort to migrate from multi-disciplinarity towards interdisciplinarity. In that regard, one of the most challenging questions that has arisen so far from MCDR's research is: Is it possible to move a multi-disciplinary team of economists, climatologists, geographers, anthropologists, biologists, sociologists, journalists, chemical engineers, environmental engineers and lawyers to work in a more interdisciplinary way? Thus, this article aims to propose elements for answering that question through a case study of one of the MCDR's sub-network research projects, concerning the climate change perceptions and the adaptation strategies of vulnerable family farmers from four Brazilian biomes (Amazonia, Cerrado, Pantanal and Semiarid).

Small-scale farmers have always adapted to climate variability in their ecosystem (Pinedo-Vasquez \& Padoch, 2009). However, in the last few years, in addition to this predictable local variability, traditional systems have to deal with changes in climate, which brings unpredictability and disruption of regular seasons. As a result, the "traditional" risks and vulnerabilities that subsistence farmers are used to experience are multiplied (Kasperson et al., 2005). Climatic stresses mostly occur during a time when productive systems are already facing other immediate modifications. In parallel to climate change, there is also an accelerated process of cultural and socio-political change, transforming the demographic composition of rural areas and the access to financial resources. While climate change makes subsistence farming both more expensive and insecure, rural populations are increasingly seeking alternatives to subsistence farming and rural life (Grainger-Jones, 2011). However, the lack of agreement on practices that family-farmers should employ to cope with climate uncertainty, place this group in a delicate situation. In this context, the analysed project, developed by the MCDR sub-network, focused on the impacts of climate change on traditional agricultural systems, with the purpose of better characterizing the complexities in the interactions between family farmers, agricultural systems and the ecosystem.

This paper does not discuss the project results (something that has been extensively done, see for instance Bursztyn \& Rodrigues Filho, 2016), but rather explores the research team internal dynamics and the main challenges faced during the creation of a shared research protocol to collect and interpret data from an interdisciplinary point of view.

The article starts by offering a short presentation about the originality of rede CLIMA's contributions, in the context of the structure and objectives of the Brazilian climate change agenda. Then, the conceptual framework and the chosen methodology (case study) are presented. Departing from the concrete challenge of framing and interpreting 
the apparent "misperceptions" of family farmers about climatic change, this work offers a reflection on the challenges of thinking collectively about a problem such as sustainability and climatic perceptions, a field that includes so much ambiguous and contradictory knowledge, conflicting interests, and diverging epistemologies (Kates, 2011).

\subsection{The Brazilian Research Network on Global Climate Change (Rede CLIMA)}

As Brazil already has multiple scientific initiatives aimed to assist the country in dealing with climate change related issues - for instance, the National Institute of Science and Technology for Climate Change (INCT-MC), and the FAPESP Program on Global Climate Change Research (PFPMCG), among others - Rede CLIMA has been evolving and changing its initial profile: moving towards aggregating and synthetizing scientific knowledge (in an interdisciplinary effort) and transforming climate change knowledge into reliable, legitimate and transparent data that stakeholders can use in decision-making (transdisciplinary effort).

Regarding its governance structure, Rede CLIMA is composed by a Board of Directors, and a Scientific Body (SB) led by a Science Coordinator (SC) and an Executive Secretariat (ES), based at the National Institute for Space Research (INPE). The Scientific body is, at present, composed of 16 thematic sub-networks: Agriculture; Biodiversity and Ecosystems; Cities and Urbanization; Natural Disasters; Regional Development; Scientific Communication; Economy; Renewable Energies; Climatic Modelling; Oceanography; Public Policies; Water- Resources; Health; Ecosystem-based Services; Land Use; and Coastal Areas ${ }^{1}$.

\section{Conceptual framework}

\subsection{Inter or transdisciplinarity?}

Rede CLIMA's fundamental nature is based on interdisciplinarity and transdisciplinarity due to the network's objectives of analysing problems arising from society (Arraut et al., 2012), which developed overtime in a strong focus on human dimensions of global environmental change. One of the first challenges rede CLIMA'S MCDR sub-network needed to address when reflecting on the developed work was precisely that of defining the concepts of interdisciplinary or transdisciplinary research.

While we considered ourselves members of an interdisciplinary research team, foreign scholars tended to define MCDR sub-network research work as clearly transdisciplinary. In fact, this apparent conceptual "confusion" was just mirroring a current debate, which seems to have an origin in geographical roots (Litre et al., 2017). In the international scientific community (mainly European and Australian

\footnotetext{
${ }^{1}$ The Science Coordinator and the Executive Secretariat are both based at INPE; the science body is comprised within the 16 sub-networks distributed throughout Brazil. The headquarters of the sub-networks are based in each of Brazil's five regions. Each sub-network operates as a network in itself, with links connecting the headquarters to other Brazilian and foreign institutions, so that, in practice, Rede CLIMA's reach and interconnectedness are much greater than what can be perceived in this figure.

Source: http://redeclima.ccst.inpe.br/estrutura/, 2017.

CLIMA's reach and interconnectedness are much greater than what can be perceived in this figure. Source: http://redeclima.ccst.inpe.br/estrutura/, 2017.
} 
research centres), there was a clear and consistent trend towards the valorisation of transdisciplinarity, as a term that highlighted the importance of stakeholders in transforming scientific knowledge into instrumental information, especially among problem-oriented researchers (Matson et al, 2016). Meanwhile, in Brazil researchers were dedicating a significant portion of produced literature to the study of interdisciplinarity (Bursztyn et al., 2016; Bursztyn \& Purushothaman, 2015).

In Brazil, the term "transdisciplinary" was even seen by many as emotionally burdened: profoundly intertwined with the field of environmental education, the concept definition included elements from the epistemology of complexity (Morin, 2005; Capra \& Luisi, 2014), and even a certain voluntarism to worship traditional environmental knowledge in opposition to a certain academic "arrogance". Without openly expressing this, many Brazilian intellectuals were silently disappointed at the vernacular meaning attributed to the term trandisciplinar, which finished being exaggeratedly linked to mysticism and religiosity. To counterbalance that trend, those intellectuals opted for the term interdisciplinarity to describe their scientific efforts in the environmental change agenda.

Currently, interdisciplinary academic programs proliferate in Brazil. Beginning in Rio-92, in just over two decades the country had over 100 master or doctoral postgraduate programs focused on themes that gravitate towards sustainability. It was the academic group that grew the most in the universe of programs accredited by the Coordination of Improvement of Higher Education Personnel (CAPES, in Portuguese). In spite of this rapid growth, the institutionalization of interdisciplinarity is still extremely complex within Brazilian universities, most of which have been conceived as disciplinary and departmentalized institutions (Buarque et al., 2014). Some other bottlenecks are the identification of specialized scientific journals dealing with interdisciplinarity for the dissemination of scientific production, a still undefined metric of evaluation of research results, and even the (un)employability of graduates from interdisciplinary programmes (Bursztyn et al, 2016).

The debate about the definitions of inter and transdisciplinarity, on its turn, seems to have been overcome by most Brazilian intellectuals, which currently follow the position of Hirsch-Hadorn et al. (2007) of defining interdisciplinarity as the necessary construction of spaces for disciplinary integration within the academic field (in a certain way, interdisciplinarity can be seen as a "hub" in which different disciplines meet and interact) (Buarque et al., 2014, Bursztyn et al., 2016). On the other side, transdisciplinarity is defined as a "gateway" that creates a bridge between scientific knowledge (scholars) and decision-makers (practitioners and stakeholders) to co-design and co-produce knowledge (Hirsch-Hadorn et al., 2007; Voorberg et al., 2015).

Besides the already mentioned bottlenecks to the institutionalization of interdisciplinarity among Brazilian universities, this articles focuses on how researchers' personal thoughts and beliefs shape the design of interdisciplinary research projects, their outcomes and their interpretation (Moon \& Blackman, 2014), a lesson that was replicated at the MCDR's research process, as demonstrated below.

\subsection{Clashing languages and epistemologies}

Disciplinary differences did not take long to emerge during the first moments of researchers' 
interaction at the MCDR network. Thinking collectively about the problems was thought-provoking since academic languages were so distinct to the point of even clashing. Thus, the challenge was to establish a real dialogue about terms such as resilience, vulnerability, adaptive capacity and even climate change, since differences went well beyond semantics and reached the core of concepts. How could we harmonize concepts in order to see a full new picture?

Reaching a collective definition of the concepts of vulnerability and resilience regarding climate change was an example. In order to accommodate the range of viewpoints and histories around these terms, the team considered the approaches of vulnerability and resilience not as antagonistic, but as complementary and aimed at answering the same question: How are socio-ecological systems affected by, and respond to, environmental disturbances? The MCDR team decided to concentrate on the theoretical and conceptual framework of vulnerability and its attributes (sensitivity, adaptive capacity and exposure), but added the notion of resilience in some of the analyses and discussions. Unlike the blind men and elephant story, where each feels a different part of the elephant, resulting in incompatible visions of the whole, the story of Rede CLIMA ends well.

\section{Methodology}

As previously explained, this paper analyses how the sub-network MCDR, through a case study in four Brazilian biomes, managed to face the interdisciplinary challenges arising during the execution of a nationwide and multidisciplinary research project on climate change perceptions from family farmers. The project was a collaborative effort that led to the completion of 1,708 interviews conducted with smallholder farmers, policy-makers and stakeholders, through 10 field studies in the Caatinga, Amazon, Cerrado and Pantanal biomes of Brazil (Figure 1).

The research project assumed that the success of climate change adaptation policies radically increases when these policies are grounded in first-hand knowledge of everyday realities and perceptions of the population concerned (in this case, family farmers). Three basic elements guided the research design of the studied project: i) the urgent demand, by the Brazilian administration, who fostered the creation of Rede CLIMA and drove the project into conducting policy-oriented research; ii) the need for creating suitable tools for the analysis of complex phenomena, such of climate change and socio-ecological systems; and, iii) the aim for obtaining comparable research results to identify particularities and similarities of climatic impacts on different biomes.

After collectively defining an initial provisional theoretical framework (Lindoso \& Rodrigues Filho, 2016), the team was organized into interdisciplinary workgroups which focused on concrete research aspects, such as 1) advancing the initial theoretical framework through the interplay between theory and empirical data; 2) climatological analysis; 3) research tools; 4) public policy; and 5) communication with stakeholders. All research groups were interdisciplinary, but the central disciplines varied. For instance, climate engineers led the analysis of rain levels and temperature oscillations from meteorological stations across the biomes, but the team also included biologists and geographers (Fetter et al., 2016). Climate change perceptions 
were the main interest of anthropologists, but the journalists, social communicators, historians and economists on that team always contributed (Curi et al., 2016a; 2016b). No questions were considered irrelevant or out of place. In the workshops organized across regions, everybody was encouraged to 'stick their nose over the fence' and participate in other workgroups. The research protocol was collectively designed to act as a roadmap (Nasuti et al., 2016a).
Questionnaires were subjected to several pre-tests with farmers, and researchers from different backgrounds were trained to make correct use of the questionnaire and tabulate data. Far from being static, the thematic axis of the questionnaires evolved along time (and research regions). These changes reflected the appropriation of the theoretical-conceptual framework by the interdisciplinary research team. Initially, in the Amazonian research,

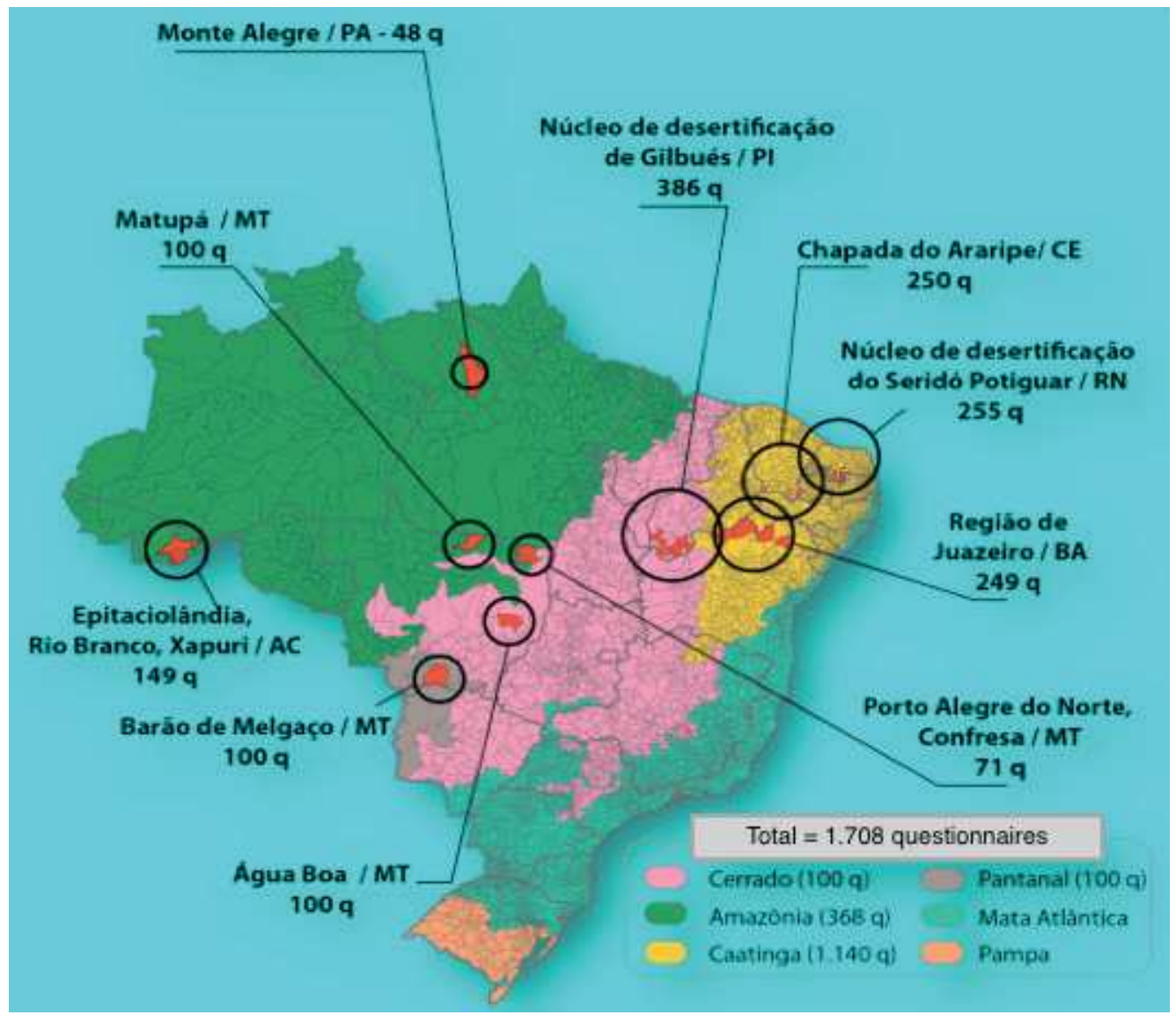

FIGURE 1 - Areas of implementation of the 1,708 interviews with smallholder farmers, policy-makers and stakeholders, through 10 field studies in the Caatinga, Amazon, Cerrado and Pantanal biomes of Brazil. "Núcleo de desertificação" stands for desertification nucleus; "q" stands for questionnaires.

SOURCE: Nasuti et al. (2016a) - adapted from IBGE (2012) and IBGE (2004). 
the attributes of sensitivity, exposure and adaptive capacity, which constitute the analytical framework of vulnerability, were still very theoretical within the research, so the questions were simpler and generalist. As the field surveys continued in new areas, the team improved its understanding of these attributes and translated this new shared knowledge in the questionnaires. Characteristics of the productive system and the demography of families provided information on sensitivity factors, while economic, technological and political-institutional aspects provided data on adaptive capacity. Questions about climate perceptions and information on impacts and damage allowed researchers identifying vectors of exposure, but also provided clues about adaptive capacity (Nasuti et al., 2016a).

The questionnaires applied in each case stu$\mathrm{dy}$, even among those from the same biome, were distinct, although they had scientific continuity. The more distant from the case studies in the chro- nological order of the research, the more distinct were the questionnaires, the most pronounced break being between the third version (Xapuri / AC case study) and the fourth version (Juazeiro / BA case study). Even so, the majority of the questions matched, allowing general comparisons. Regarding the formal structure of the questionnaires, the main differences were the total number of questions asked and, in the case study of the Chapada do Araripe / $\mathrm{CE}$, the inclusion of a new section on the specific issue of food safety and he drought of 2012 (Table 1).

\section{Results}

During the analysis and interpretation of the project research results, interdisciplinary interaction was also existent and debated (Litre et al., 2016; Nasuti et al., 2016b; Silva et al., 2016; Simoni et al., 2016). The perceptions of some farmers did

TABLE 1 - Comparison and evolution of the thematic axes of the 1708 questionnaires applied in each study area, classified by year of research, city and state within Brazil, and project funding agency $(*, * *, * * *)$.

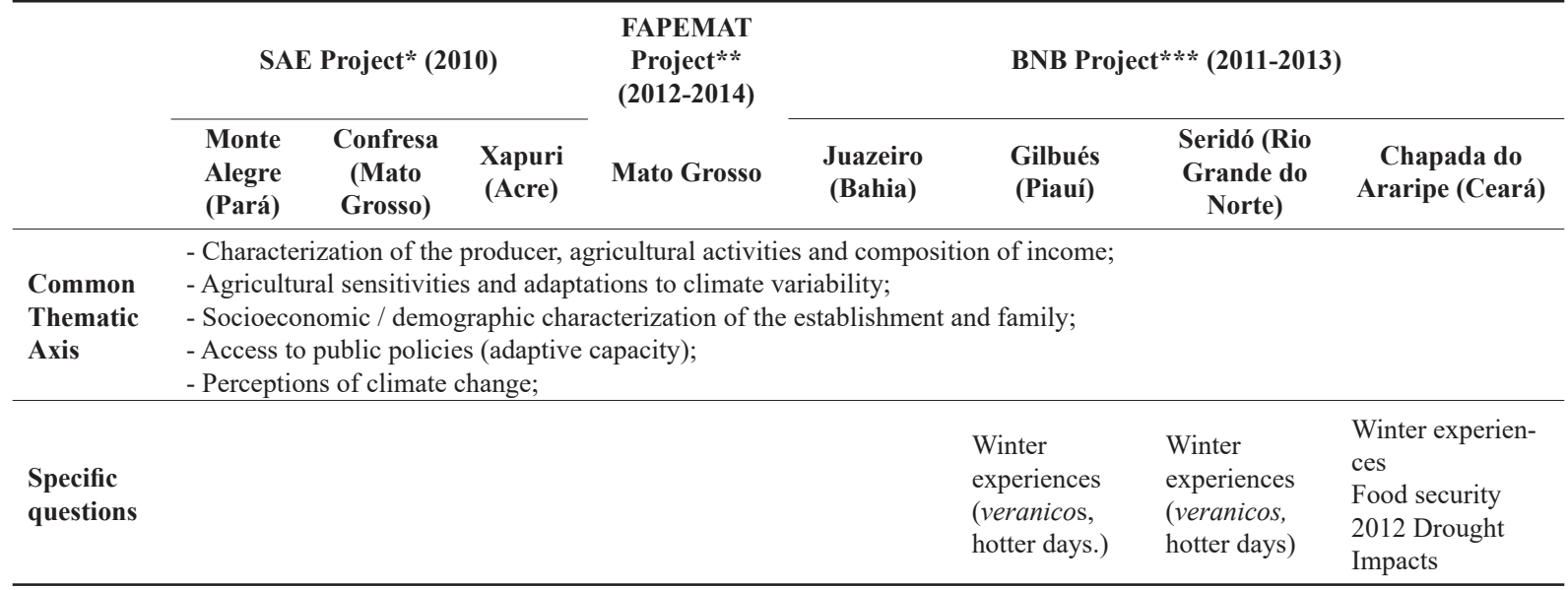

SOURCE: Adapted from Nasuti et al. (2016a).

* Funded by the Strategic Issues Secretary of the Presidency of the Republic; ** Funded by the Research Support Agency of Mato Grosso; *** Funded by the Bank of the Northeast of Brazil. 
not always coincide with the climatological data analysis, with some farmers describing a reduction in mean precipitation levels in regions where such decrease did not occur (according to meteorological analysis) (Nasuti et al., 2016c). This led to considerable discussion and debate among researchers with different social science backgrounds, about why such perceptions had occurred and the ethics of investigating them and potentially disrespecting traditional knowledge. The labelling of this phenomenon was also discussed (Curi et al., 2016b): Should it be called misperceptions? False perceptions?

To offer some background behind the encountered mismatch, during the initial project stages, a part of the research team focused on the study of annual and monthly rainfall reduction trends in different biomes and regions, using data generated by hundreds of meteorological stations (Fetter et al., 2016). The team included climatologists, geographers, geologists, environmental engineers, biologists and ecologists. In a second stage, regions with and without precipitation decreases in a 30-year span were selected as field location for the case studies and surveys. By an impressive majority, farmers recognized important climate change signs, including temperature rises (proven by meteorological data nationwide) and rainfall level decreases, which happened only in some regions. These findings raised questions about how and why the perceptions of some farmers did not consistently coincide with local climatological data.

To start with, and since the term misperception does not exist in the Portuguese language (our main working language in Brazil), the very choice of a word describing the mismatch between perceptions and climate data was a challenge. The team ended up translating the neutral term misperceptions as falsas percepções, or false perceptions, even if the expression carried a risk of unintentionally (and wrongly) suggesting that family farmers are unable to accurately decipher any climatological signs. In fact, they were right when pointing out their cultivations and crops were receiving less water, even though the origin of this perception was misunderstood (or misattributed).

Unsurprisingly, the diverse hypotheses about the origins of climate change misperceptions came from the MCDR sub-network's different backgrounds and expertise. For instance, social communicators and sociologists suspected that surveys might had asked a flawed question, unintentionally leading the answers towards the confirmation of rainfall level decreases, or just to please the interviewers (farmers knew they were climate researchers). Alternatively, it was suspected that respondents might had been blindly echoing apocalyptic messages received in their remote regions, through the omnipresent and far-reaching mass media. Overall, none of these really seemed to be the case. As for the influence of mass media, even if radios and TVs were a real influence in their humble homes, they were not blind at all, as proven by the richness of their answers.

The discovery of climate change misperceptions (which have also been raising noteworthy research questions in other countries, such as Kenyasee for example Rao et al., 2011) also originated interesting interactions between disciplines within Rede CLIMA. To strength the analysis in course, the network included a journalist with a background in economics, rural sociology and geography, in addition to two other participating post-doctoral researches, which decided to collectively reflect on the theoretical and practical implications of the 
apparent clashes between subjective perceptions on climate change and objective (science-based) climatological information. The other two researchers had frequently interacted with social movements and minorities, as a lawyer/anthropologist with experience in the fields of indigenous peoples' rights, and as an anthropologist/sociologist who had performed research on indigenous peoples and slave labour.

The journalist/geographer used cognitive psychology and sociological theoretical tools to explore how perceptions evolved depending on farmers' previous life experiences, needs and personal motivations, wishing to describe the impacts of perceptual defence and cultural barriers. In other words, the understanding of how and why people tended to unconsciously ignore or disregard things that were possibly interpreted as negative or threatening to their livelihoods was expected, paying special attention to what was perceived as rewarding.

Interestingly, while the journalist/geographer observed its own personal approach as a mere objective analysis of fieldwork results on climate change perceptions, the anthropologists showed ethical concerns, especially about the political impacts of eventual results. In other words, they worried about the risk of an implicit underestimation, or even devaluation, of the rich local knowledge and perceptions of traditional communities, which could have a negative impact in affirmative policies for those already neglected groups and their environments. As a manner to decrease those concerns, the team agreed to analyse climate change misperceptions through the more "politically-appropriate" Climate Anthropology theoretical framework. This approach allowed the involved researchers to describe the clashes between reality and subjectivity as simply different translations of rich sociocultural experien- ces of traditional peoples with their environment, which may, or may not, coincide with existing scientific studies. To make a long story short, the same interdisciplinary team discovered that, when farmers declared that they perceived steady rainfall level reductions in their regions, they were trying to make sense of the dryness leading to important agricultural losses.

The detailed statistical analysis of meteorological data from three decades showed that in fact rainfall levels were not changing, but the occurrence, duration and frequency of dry spells (veranicos, in Portuguese) during the rainy season were more frequent (Fetter et al., 2016). Veranicos are one of the main climatic adversities limiting agricultural production in Brazil (Marengo et al., 2011). Another relevant factor was evapotranspiration, which, in addition to precipitation, is the most significant component of the hydrologic balance. Evapotranspiration varies regionally and seasonally, and according to weather and wind conditions (Wang \& Dickinson, 2012). This variability, especially during the drought periods, have clear policy implications for Brazilian decision-makers: water managers who are responsible for planning and adjudicating the distribution of water resources need to have a thorough understanding of the evapotranspiration process, including knowledge on spatial and temporal rates. Farmers had indeed perceived the indirect impacts of alterations of veranicos, even though they could not find the scientific words to describe it: many of the oldest interviewees declared flowers were blossoming earlier or later in the year and that certain bird species had changed migration routines.

Going back to the role of Climate Anthropology in the interpretation of our results, this discipline reminded us that every perception is, by definition, 
subjective, and that human subjectivity is largely influenced by cultural, traditional, social, educational, and economic factors (Tuan, 1983; Ingold, 2000). In this regard, the study of misperceptions through this perspective may provide interesting ethnographic information on how targeted communities interpret climate change and variability, as well as the practical consequences that those perceptions have on their livelihoods (Curi et al., 2016b).

By welcoming new research approaches, such as Climate anthropology, and strengthening the implementation and outcomes of interdisciplinary climatic-research, it might be possible to understand what may become maladaptive production practices in response to climate change misperceptions. Additionally, such information may contribute to the creation of more realistic and down to earth adaptation and mitigation polices at regional and national scales.

\section{Conclusion}

Interdisciplinary clashes among scientists affiliated to the Rede CLIMA's sub-network on Climate Change and Regional Development went well beyond semantics and reached the core of concepts such as perception, resilience, vulnerability, adaptive capacity and even climate change. Challenges included thinking collectively about problems with considerable ambiguous and contradictory knowledge, conflicting interests, and diverging epistemologies.

Even if the research protocol design that had been collectively planned to act as conceptual roadmap was successful in helping to define the common scope and purpose of the research integration and implementation, each case study ended up including ad-hoc consultation and knowledge co-production methods to integrate culturally diverse partners in different phases of the projects. Thus, this case study confirms that a blueprint for transdisciplinary climate change research projects is far from existent, as well as the clear need for project-specific and context-sensitive research strategies.

A critical factors going into our successful interdisciplinary and transdisciplinary integration included the early involvement of different groups (such as researchers, decision-makers, local actors and stakeholders) as essential for finding common objectives and priorities. In spite of the lengthy, energy consuming and sometimes frustrating experience, interdisciplinary efforts were paid off in terms of communicative and integrative competencies, which proved to be incredibly beneficial for effective science-policy interaction.

As potential users might become more likely to overcome cultural and cognitive barriers and trust knowledge when having a close relationship and facing research results produced by an interdisciplinary team, they may become key players in climatic policies, especially when saliency (relevancy), credibility and legitimacy are present. The experience of Rede CLIMA confirmed that barriers to successful climate change adaptation (such as the mutual incomprehension or distrust between scientists themselves and between scientist and end-users) could be overcome by creating collaborative, transdisciplinary enterprises. The co-creation of science, which included switching roles between knowledge producers and end-users, facilitated horizontal work and the identification of climate-related risks among family farmers, together with a solid interdisciplinary team, was indispensable to this research, being suggested as an important approach to be used by groups in similar working fields and subjects. 


\section{References}

Arraut, E. M.; Nobre, P.; Nobre, C. A.; Scarpa, F. M. Brazilian Network on Global Climate Change Research (Rede CLIMA): structure, scientific advances and future prospects. Sustentabilidade em Debate, 3(2), 241-256, 2012. Disponível em: http:// seer.bce.unb.br/index.php/sust/article/view/8136/6172

Buarque, C.; Ferreira, L.; Jacobi, P.; Sobral, M. do C.; Sampaio, C. A.; Fernandes, V.; Litre, G.; Bursztyn, M.; Drummond, J. A. interdisciplinaridade e o enfrentamento aos desafios da sustentabilidade. Sustentabilidade em Debate, 5(1), 183-195, 2014.

Bursztyn, M.; Rodrigues Filho, S. (Org.). O Clima em Transe: vulnerabilidade a adaptação da agricultura familiar. Rio de Janeiro: Garamond, 2016.

Bursztyn, M.; Maury, M. B.; Litre, G. Interdisciplinary Graduate Studies in Brazil: Lessons From Sustainability and Environmental Sciences. Issues in Interdisciplinary Studies, 34, 123143, 2016. Disponível em: https://eric.ed.gov/?id=EJ1171318

Bursztyn, M.; Purushothaman, S. Interdisciplinarity: Topping the Charts. Nature, 526, 323-323, 2015.

Capra, F.; Luisi, P. L. The Systems View of Life: A Unifying Vision. Cambridge University Press, 2014.

Curi, M.; Litre, G.; Veiga, A. P. S. O compromisso com a restituição de resultados da pesquisa. In: Bursztyn, M.; Rodrigues Filho, S. (Org.). O Clima em Transe: vulnerabilidade a adaptação da agricultura familiar. 1ed. Rio de Janeiro: Garamond, 2016a, p. 77-92.

Curi, M.; Litre, G.; Ibiapina, I.; Andrade, A. J. P. Mudanças Climáticas e Percepção Ambiental: Contribuições da Antropologia do Clima. In: Bursztyn, M.; Rodrigues Filho, S. (Org.). O Clima em Transe: vulnerabilidade a adaptação da agricultura familiar. Rio de Janeiro: Garamond, 2016b, p. 35-52.

Fetter, R.; Oliveira, C. H.; Debortoli, N.; Saito, C. H. A contribuição da análise espaço-temporal de dados climáticos. In: Bursztyn, M.; Rodrigues Filho, S. (Org.). O Clima em Transe: vulnerabilidade a adaptação da agricultura familiar. Rio de Janeiro: Garamond, 2016, p. 219-245.

Grainger-Jones, E. Climate-smart smallholder agriculture: What's different? IFAD occasional paper, $\mathrm{n}^{\circ} 3$, International Fund for Agricultural Development, 2011.
Hirsch-Hadorn, G.; Hoffmann-Riem, H.; Biber-Klemm, S.; Grossenbacher-Mansuy, W.; Joye, D.; Pohl, C.; Wiesmann, U.; Zemp, E. Handbook of Transdisciplinary Research, Springer, 2007.

Hogan, D. J. Human Dimensions of Global Environmental Change. Ambiente \& Sociedade, 10 (2), 161-166, 2007. Disponível em: http://www.scielo.br/pdf/asoc/v10n2/a11v10n2.pdf

IBGE. Mapa de biomas do Brasil: primeira aproximação. Rio de Janeiro, IBGE: 2004.

IBGE. Malha Municipal Digital do Brasil: situação em 2000 e 2010. Rio de Janeiro, IBGE, 2012. Disponível em: ftp:/geoftp.ibge.gov.br/organizacao_do_territorio/malhas_territoriais/ malhas_municipais/municipio__2010/

Ingold, T. Perception of the Environment: Essays on livelihood, dwelling and skill. Routledge, London, 2000.

Janssen, M. A.; Schoon, M. L.; Ke, W.; Börner, K. Scholarly networks on resilience, vulnerability and adaptation within the human dimensions of global environmental change. Global Environmental Change, 16(3), 240-252, 2006.

Kasperson, R.; Dow, K.; Archer, E. et al. Vulnerable peoples and places. In: Hassan, R. M.; Scholes R. J.; Ash N. (Eds.). Ecosystems and human well- being: current state and trends findings of the conditions and trends working group, Millennium Ecosystem Assessment. Washington, Island Press, 2005.

Kates, R. W. What kind of a science is sustainability science? Proceedings of the National Academy of Sciences of the United States of America, 108(49), 19449-19450, 2011.

Kuhn, T. S. The Nature and Necessity of Scientific Revolutions. The Structure of Scientific Revolutions. Chicago: University of Chicago Press, 1962.

Lindoso, D. P.; Rodrigues-Filho, S. Vulnerabilidade e Adaptação: Bases Teóricas e Conceituais da Pesquisa. In: Bursztyn, M.; Rodrigues-Filho, S. (Org.). O clima em Transe: vulnerabiidade e adaptação da agricultura familiar. Rio de janeiro: Garamond, 2016, p. 19-33.

Litre, G.; Bursztyn, M.; Rodrigues-Filho, S.; Lindoso, D. Insights Into a Transdisciplinary Case Study in an Intercultural Context: The Experience of the Brazilian Research Network on Climate Change (Rede CLIMA). Oral Presentation at the International Transdisciplinarity Conference 2017 - Transdis- 
ciplinary Research and Education - Intercultural Endeavours, September 11-15, 2017, Leuphana University Lüneburg, Germany. Conference Website: http://www.transdisciplinarity.ch/ en/td-net/Konferenzen/ITD-2017/Detailed-programme.html

Litre, G.; Silva, C. J.; Silveira, J. S.; Nogueira, P.; Lima Facanha, C.; Saito, C.; Fetter, R.; Freitas, S.; Napolis, P. Estudos de Caso - Cerrado. In: Bursztyn, M.; Rodrigues Filho, S. (Org.). O Clima em Transe: Vulnerabilidade e Adaptação da Agricultura Familiar. Rio De Janeiro: Garamond, 2016, p. 139-173.

Marengo, J. A.; Alves, L. M.; Beserra, E. A.; Lacerda, F. F. Variabilidade e mudanças climáticas no semiárido brasileiro. In: Medeiros, S. S. M.; Gheyi, H. R.; Galvão, C. O.; Paz, V. P. S. (Org.). Recursos Hídricos Em Regiões Áridas e Semiáridas. Instituto Nacional do Semiárido, Campina Grande, 2011, pp. $1-40$.

Matson, P.; Clark, W. C.; Andersson, K. Pursuing Sustainability. A Guide to Science and Practice. Princeton and Oxford: Princeton University Press, 2016.

Moon, K.; Blackman, D. A Guide to Understanding Social Science Research for Natural Scientists. Conservation Biology, 28(5), 1167-1177, 2014.

Morin, E. Introdução ao pensamento complexo. Sulina, Porto Alegre, Brasil, 2005.

Nasuti S.; Lindoso, D.; Litre, G. Limites e Potencialidades da Pesquisa Interdisciplinar sobre Adaptação Climática: $\mathrm{O}$ Protocolo de Pesquisa da Sub-Rede Mudanças Climáticas e Desenvolvimento Regional. In: Bursztyn, M.; Rodrigues Filho, S. (Org.). O Clima em Transe: vulnerabilidade a adaptação da agricultura familiar. Rio de Janeiro: Garamond, 2016a, p. 53-76.

Nasuti, S.; Rocha, J. D.; Viana, C.; Saito, C. H.; Souza, R.; Chacon, S. S. Estudos de Caso - Semiárido. In: Bursztyn, M.; Rodrigues Filho, S. (Org.). O Clima em Transe: vulnerabilidade a adaptação da agricultura familiar. Rio de Janeiro: Garamond, 2016b, p. 115-137.

Nasuti, S.; Litre, G.; Garcz, C. G.; Silva, C. J.; Nogueira, P. Percepções de pequenos agricultores sobre o clima: Comparação entre os biomas Amazônia, Cerrado, Caatinga e Pantanal. In: Bursztyn, M.; Rodrigues Filho, S. (Org.). O Clima em Transe: vulnerabilidade a adaptação da agricultura familiar. Rio de Janeiro: Garamond, 2016c, p. 197-217.
Pinedo-Vasquez M.; Padoch C. Urban, rural and in-between: multi-sited households mobility and resource management in the Amazon flood plain. In: Alexiades, M. N. Mobility and migration in indigenous Amazonia. Contemporary ethnoecological perspectives, 2009.

PNMC. Plano Nacional de Mudança do Clima. Ministério do Meio Ambiente, Brasil, 2008. Disponível em: http://www. mma.gov.br/estruturas/smcq_climaticas/_arquivos/plano_nacional_mudanca_clima.pdf.

Rao, K. P. C.; Ndegws, W. G.; Kizito, K.; Oyoo, A. Climate Variability and Change: Farmer Perceptions and Understanding of Intra-Seasonal Variability in Rainfall and Associated Risk in Semi-Arid Kenya. Experimental Agriculture, 47(2), 267-291, 2011.

Silva, C. J.; Nogueira, P.; Silveira, J. S.; Litre, G.; Costa, J.; Sander, N.; Lima Facanha, C.; Viana, I.; Henke, C. Estudos De Caso - Pantanal. In: Bursztyn, M.; Rodrigues Filho, S.. (Org.). O Clima em Transe: vulnerabilidade a adaptação da agricultura familiar. Rio de Janeiro: Garamond, 2016, p. 173-196.

Simoni, J.; Rocha, J. D.; Mesquita, P. S.; Lindoso, D.; Debortoli, N.; Ibiapina, I.; Araújo, J. Estudo de caso - Amazônia (Pará e Acre). In: Bursztyn, M.; Rodrigues Filho, S. (Org.). O Clima em Transe: vulnerabilidade a adaptação da agricultura familiar. Rio de Janeiro: Garamond, 2016, p. 93-113.

Smit, B.; Wandel, J. Adaptation, adaptive capacity and vulnerability. Global Environmental Change, 16(3), 282, 2006.

Tuan, Y. Topofilia: Um Estudo da Percepção, Atitudes e Valores do Meio Ambiente. Difel, São Paulo, 1983.

Voorberg, W. H.; Bekkers, V. J. J. M.; Tummers, L. G. A systematic review of co-creation and co-production: Embarking on the social innovation journey. Public Management Review, 17(9), 1333-1357, 2015. doi: 10.1080/14719037.2014.930505

Wang, K.; Dickinson, R. R. A review of global terrestrial evapotranpiration: Observation, modelling, climatology and climatic variability. Reviews of Geophysics, 50(2), 1-54, 2012. doi: 10.1029/2011RG000373 